\title{
Impact of women dairy co-operative societies on empowerment of women members
}

\author{
GAGANDEEP KOCHAR* AND SUKHJEET KAUR \\ Department of Home Science Extension and Communication Management, Punjab Agricultural \\ University, LUDHIANA(PUNJAB) INDIA
}

\begin{abstract}
Dairy co-operatives are playing a prominent role in the development of dairy industry as well as to increase the income of rural people. Livestock sector in India has experienced remarkable growth during the last two decades in terms of production, value addition and trade. Livestock sector contributes nearly 25 per cent to the gross value of agricultural output at the national level. The role played by women in dairy farming is worthy enough to compare with their male counterparts. In commercial dairy farming, women seem to monopolies almost all the dairy operations, however, their participation is less only in health care aspects of dairy animals. Women actively participate and take decision with regard to management of dairy animals, production and processing aspects of dairying. Women dairy projects being implemented under "Support to Training and Employment Programme (STEP)" for women by the Department of Women and Child Development, Ministry of Human Resource Development, Government of India. STEP is being implemented to ensure well-being of women in traditional informal sectors. It aims at increasing self-reliance of women by enhancing their productivity and enabling them to take up income generation activities. A number of state level dairy federations took up organizing women dairy co-operative societies under STEP. Women dairy co-operative system is owned, controlled and managed by women only. It was, therefore, planned to focus attention on functioning of women co-operative societies and their impact on empowerment of members. The present study investigated the impact of women dairy co-operative societies on empowerment of women members. A sample of 150 members was selected through proportionate random sampling technique. Thus, the study was carried out on 150 members of Women Dairy Co-operative Societies. The data were collected with the help of interview schedule. Majority of the respondents reported that there was improvement in economic resources of the family, women's own development, decision making capacity regarding education and marriage of children and participation in social activities.
\end{abstract}

KeY Words : Empowerment, Dairy co-operatives, Women members

View Point Article : Kochar, Gagandeep and Kaur, Sukhjeet (2015). Impact of women dairy co-operative societies on empowerment of women members. Internat. J. Home Sci. Extn. \& Comm. Manage., 2 (2): 84-89.

Article History : Received : 14.03.2015; Revised : 18.05.2015; Accepted : 19.06.2015

\footnotetext{
* Author for correspondence
} 